\title{
MORAL RENEWAL AS A SOCIO-RELIGIOUS IMPERATIVE AND THE DESTRUCTIVE ACTIONS OF AN OPPRESSIVE TOTALITARIAN STATE: IN THE CONTEXT OF CARDINAL STEFAN WYSZYŃSKI'S PERSONALISTIC CONCEPT OF SOCIAL LIFE
}

\begin{abstract}
The historical legacy and destructive actions of the oppressive totalitarian state of the post-war Polish Peoples' Republic were associated with severe threats to the Nation's socio-cultural existence. In this context, the seriousness of the situation was related to both geopolitical conditions and several systemic shortcomings of the communist state, ideologically hostile to Christianity, as well as to native culture. However, dangerous addictions and national moral flaws also played an important role. Therefore, the specificity of the situation demanded an absolute opposition to the above problems on the part of all social structures of the Nation. According to Cardinal Wyszyński, it was not only about overcoming one or another national-moral defect, but a comprehensive moral transformation in the spirit of Christian culture was required, which could become a religious and social program for the moral rebirth of the entire Nation.

Thus, moral renewal has become an indispensable condition for positive changes in Poland. It is realized in the community of the Church by proclaiming the Gospel message of redemption accomplished in Jesus Christ and calling for fidelity to the baptismal sacramental grace. At the same time, it displayed the ways and means of renewing all socio-cultural structures in their specific historical reality. Unfortunately, the programmatic process of secularization and atheization carried by employing various means and methods posed a significant threat to Poles' culture and identity and the Nation's religious and moral life.

Therefore, the foundation for social life's moral renewal was a rebirth in Christ, realized through metanoia and reconciliation with God in the Church. However, this process requires a radical turn towards God, which results in a change of consciences and a deepening of the human person's consciousness and moral sensitivity, family, and, consequently, the nation. Nevertheless, a change in thinking and evaluating of conscience entails a shift in attitudes that, oriented towards holiness, would lead to Christian perfection in Christ. Thus, the return to God through Marian devotion (Soli Deo per Mariam) becomes the fundamental basis of the moral renewal of social life's whole reality. It takes place both through a continuous transformation of hearts and attitudes of individual
\end{abstract}

Rev. RYSZARD FICEK, STD, Ph.D. - priest of the diocese of Rockville Center/NY, the moral theologian and political scientist, a former lecturer of the Jordan University College in Morogoro/Tanzania, specializing in the moral theology, church history and international relations; address for correspondence-e-mail: rficek@optonline.net; ORCID: https://orcid.org/0000-0001-5238-6767. 
people as well as the entire community in the dimension of sacramental reconciliation with God in the Church.

Key words: Cardinal Stefan Wyszyński; totalitarian ideology; communism; personalism; secularization; atheization; moral renewal.

\section{INTRODUCTION}

Severe threats to social life, resulting from geopolitical conditions and the many systemic shortcomings of the communist oppressive totalitarian state, dangerous addictions, and moral defects, required unquestionable resistance from all social structures. As Cardinal Wyszyński put it, it was not only about overcoming such or other "Polish national defects" but about a comprehensive and wide-ranging moral transformation. The above process may become a religious and social program for the Polish nation's rebirth in a broader context. "The life of a nation or state is so complex and demanding that it requires the joining of hands, hearts, and brains of all the children of the nation, all citizens of the state, without distinguishing between their social and professional environment. Then it is possible to steer the boat of our common homeland, for which we all must care".

The pastoral ministry and spiritual leadership of Primate Wyszyński fall on the post-war period of Polish history, the existence of which was seriously threatened by the most immoral totalitarian systems of the $20^{\text {th }}$ century: Nazi National Socialism and the Marxist-Leninist system of real socialism. Thus, the very complicated socio-political context, as well as the conditions of the international situation, required great prudence from the Catholic Church, but also decisive action. ${ }^{2}$

Therefore, Primate Wyszyński, as the leader of the Catholic Church in Poland, perceived the need to change the structures of public life in the country but did not consider it to be the primary and immediate task of the Church. Nor did he feel that he was called to change the political regime. His criticism primarily concerned the anthropological and moral dimensions of social life. However, the Primate was aware that the state's political system's critical elements would be necessarily changed if there were an appropriate moral order.

\footnotetext{
${ }^{1}$ S. WYSZYŃSKI, "Przywódca ludu rolniczego. Poświęcenie tablicy ku czci Wincentego Witosa. Warszawa 28.12.1975”, in: IDEM, „Nie rzucim ziemi...” Z przemówień do rolników (Warszawa: Wydawnictwo ATK, 1984), 23-24.

${ }^{2}$ Ibidem.
} 
He has repeatedly spoken of a "social disposition" that would favor just social transformation. Though social disposition - in his opinion - should be based on the Christian religion's canvas, which aims to change the human heart (metanoia). In this way, changed people become the right subject and base for the proper shaping of the common good. ${ }^{3}$

\section{TOTALITARIANISM: GENESES, TRAJECTORY, INTERCONNECTION}

Taking into account the specificity of the totalitarian systems that affected the reality of Poland, it should be noted that these are ideological concepts rooted in the horror of the events of the $20^{\text {th }}$ century, the nightmare of two modern world wars, the Bolshevik revolution, terror, genocide, and since 1945 also the threat of the total nuclear annihilation. It is also one of the most ambiguous and controversial terms in the entire lexicon of political theology. Simply put, the above idea suggests that despite fascist/Nazi "particularism" (the central place of the nation or master race) and Bolshevik "universalism" (the pursuit of classless, international communitarian brotherhood), both regimes shared common characteristics. It does not mean, however, that they were completely alike. ${ }^{4}$

Totalitarianism, extreme in its rejection of freedom, expressed its radical ambition to subordinate the whole reality of public life to a single center of power. In other words, its primary goal was power without legal and moral limitations, civic pluralism and party rivalry, and, above all, the transformation of human nature itself "into the image and likeness" of false anthropology based on the ideological premises of erroneous axiology serving the total subordination of man to the then-current political concept of the state. ${ }^{5}$

\footnotetext{
${ }^{3}$ Cf. S. WySZYŃSKI, "Czas to miłość. Podczas uroczystości Wniebowzięcia Matki Bożej (Jasna Góra, 15.08.1979)”, in: Nauczanie społeczne 1946-1981 (Warszawa: ODISS,1990), 889-891.

${ }^{4}$ Cf. I. Kershaw, M. Lewin, Stalinism and Nazism: Dictatorships in Comparison, (U.K.: Cambridge University Press, Cambridge, 1997).

${ }^{5}$ Speaking of the so-called "incomplete" systemic concepts, Cardinal Wyszyński primarily has in mind liberal capitalism and predominantly materialistic collectivism. According to him, both systems - both liberal capitalism (especially in its original form) and political and economic collectivism - turned out to be ineffective, of course, in different dimensions. In other words, neither one nor the other political and economic concept has met society's hopes and expectations (cf. S. WYSZYŃSKI, "Nasze dezyderaty. Do profesorów katolickiej nauki społecznej. (Jasna Góra, 22.01.1963)", in: Nauczanie spoteczne, 196). "The fact that the communist states based their economy on the capitalist labor system is simply the fruit of the derivative of collectivism with capitalism. This is their original sin. For both systems stem from the same materialistic philosophy, both practically proclaim the priority of things over the person - and both do not effectively defend man against the demon of technocratism who has put himself at the service of economics against the rights of the human person" (IDEM,
} 
Thus, totalitarianism is a form of a socio-political system whose essential feature is the striving for strict subordination and constant control over all areas of social and individual life. ${ }^{6}$ Its characteristic feature is also striving for the most significant possible obedience of individuals within the community. Thus, it can be concluded that the totalitarian system seems to be a specific type of political gnosis consisting of dividing reality into two dimensions: good and evil. ${ }^{7}$ This first dimension - understood as "positive" - consists of supporters of a given system. The second one is "negative" and includes enemies of the regime. Moreover, totalitarianism is often associated with dictatorship, significant restriction of civil and personal freedoms, the abolition of the freedom of speech and religion, limitation of the inviolability of private property, and the persecution of individuals opposing the totalitarian form of government. ${ }^{8}$

In the post-war period of Polish history, the revolutionary, exclusive, and apocalyptic-totalitarian ideology of the real socialism foreshadowed the destruction of the entire old order - according to Communist ideologues, corrupt and discredited by social injustice - and the birth of a radically new, purified in the Communist ideology, and, therefore, full of fresh hopes. In this context, the anti-liberal, anti-conservative, and anti-pluralist totalitarian ideology created various myths, catechisms, cults, ceremonies, and rituals to commemorate the elect's fate. The cellular, fluid, network-like political party structure handed over

\footnotetext{
"Problem pracy górników w Polsce. List do księdza biskupa Herberta Bednorza 2.02.1978", in: Nauczanie spoteczne, 810-811).

${ }^{6}$ The concept of totalitarianism, like the concept of authoritarianism as a political system, was developed after World War I and originally had positive connotations. It arose out of criticism of parliamentary democracy as a decadent and anomalous plutocracy that was opposed by a power-based state. Then the slogans were taken over by democratically oriented opponents of authoritarian movements, giving them a negative connotation. In a broad sense, authoritarianism encompasses all undemocratic forms of government, including totalitarianism as its most extreme form, as the complete opposite of democracy. Some theorists have doubts about the empirical usefulness of the concept of totalitarianism, replacing it with the idea of authoritarianism. Cf. A. PERLMUTTER, Modern Authoritarianism. A Comparative Institutional Analysis (New Haven, Conn.: Yale University Press, 1981).

${ }^{7}$ Cf. J.M. BocheŃSKI, G. NIEMEYER, Handbuch des Weltkommunismus (Fribourg-München: Alber, 1958), 633.

${ }^{8}$ Cf. A. BorowsKi, "Social interactions in the public space in the context of public confidence", International Letters of Social and Humanistic Sciences (2014), 25:33-41. Totalitarian communist ideologies always tend to transform into a kind of universal creed (a kind of "Communist Manifesto"). So a tendency that is completely lacking in liberal political systems. Because here, the rational dimension of human nature is a unifying force, assuming that humanity is the total of individual rational beings. Liberal political systems distance themselves from such understood "unity" as well as from the universality of human values understood in this way, thus representing a specific form of pragmatism. Cf. A.C. MACINTYRE, Marxism and Christianity (New York: University of Notre Dame Press, 1984), 57-75.
} 
political power to "local fighters" for new world order. As recruits and fellow believers were won over, the communist party took on an increasingly mass-populist. It was headed by a charismatic leader who demanded recognition of his omniscience and infallibility as well as unconditional personal devotion to the people (the cult of the leader). ${ }^{9}$

In the official program version, the first and principal aim of Marxism-Leninism was to transform the traditional "bourgeois state" into a "socialist state". This process was supposed to be realized through a proletarian revolution led by professional revolutionists, the working and peasant class, which had matured to revolutionary consciousness through dialectical class struggle. At this level of the revolution, the socialist state - represented in Marxist-Leninist terminology as the "dictatorship of the proletariat" - was to be led exclusively by the revolutionary party vanguard, through the process of the so-called "democratic centralism" defined as "diversity in the discussion, unity in action". ${ }^{10}$

The second idea characteristic of totalitarianism is the fascination with the "pagan" quasi-ritual. This notion is applied to fascist dictatorship, National Socialism, as well as Marxism-Leninism.

Marxism-Leninism in particular, however, officially displayed the features of a highly integrated and coherent religion that sought to resolve the fundamental dilemmas of human life. The above ideology even aspired to include with its influence those spheres of life that are beyond its prophetic interest, which seems to be its generic essence. Marxist-Leninist ideology often used peculiar quasi-religious rhetoric that time and again expressed itself through various political, economic, scientific, and philosophical statements, apparently distant from the religious dimension. ${ }^{11}$ By rejecting humanism, individualism, and democracy in the name of the universal liberation of the "New Communist Man," Marxist-Leninist ideology has become an orientation of a new spirit. Nevertheless, it was an epiphany of a totally distorted spirit (atheistic materialism). As a harmful attempt to apply the "new Middle Ages", to establish an ontical order of unity between spirit and matter, this kind of communist ideology became exceedingly dangerous.

\footnotetext{
${ }^{9}$ Cf. R. FiceK, Christians in Socio-Political Life: An Applied Analysis of the Theological Anthropology of Cardinal Stefan Wyszyński (Toruń: Marszałek, 2020), 159-162.

${ }^{10}$ Cf. M. Albert, R. Hahnel, Socialism Today and Tomorrow (Boston, Massachusetts: South End Press, 1981), 24-25.

${ }^{11}$ Cf. E. Gentile, "The Sacralization of Politics: Definitions, Interpretations, and Reflections on the Question of Secular Religion and Totalitarianism", Totalitarian Movements and Political Religions (2000), 1,1: 28-34.
} 
In this sense, Marxist-Leninist doctrines can be understood as the usurpation of transcendence intended to be produced in sweatshops and a peasant barn. ${ }^{12}$

For many researchers, therefore, communism was not a typical reaction to capitalism, but Christianity. In this sense, communism as an ideology was a consequence of an unfulfilled and unrealized Christian ideal. Moreover, communist ideology, interpreting the whole reality and creating an eschatological theory of a perfect society, ceased to be the direction of political thinking, but became the purest religion. The above doctrine understood as religion believed - at least theoretically - in the realization of the kingdom of happiness on Earth, not only without God's participation but also without human participation. ${ }^{13}$

A personalistic vision of social life as understood by Stefan Wyszyński, then, requires a firm opposition to concepts referring to dialectical materialism and breaking with the false idea of man and the world, dehumanizing and degenerating social life in all its dimensions. Otherwise, the atheistic-materialistic vision of life, entailing various forms of desacralization and dehumanization of human activity, becomes not only an expression of false ideology but also presents a real threat to both man and the entire world. Man, rejecting his reference to God in relation to the world, does not fully recognize the laws governing this world, and then the world turns against him. ${ }^{14}$

In its ideology, totalitarianism repeatedly referred to the so-called "religious war", which demands total sacrifice on the revolution's advocate. The myth of rebirth was of particular importance. It meant the creation of a new nation or a world without classes and the formation of a disinterested "New Man", untainted by decadent cultural habits referring to traditional philosophical and theological systems. The strategy of the coup d'état, the constant struggle to defeat the "enemies of the people," and the continual emphasis on the need to intensify the class struggle fostered the formation of a similar mentality among the communist leaders. ${ }^{15}$

\footnotetext{
${ }^{12}$ Cf. N. BiERDiAJEw, "Marksizm, czyli fałszywa religia", in: M. BANKowicz (red), Krytycy marksizmu, (Kraków: Wydawnictwo Uniwersytetu Jagiellońskiego, 2014), 43-5.

${ }^{13}$ In this sense, as Nikolai Berdyaev states: There is no man, there is class. And when the social classes are gone, there will be no more human personality. Only a social collective, a communist society, will remain. Communism is social idolatry. The denial of God necessarily leads to the creation of false gods. And this collective to which God is worshiped takes place destined for God and man. Individual consciousness, individual reason, and individual freedom disappear. Consciousness, reason, and collective freedom arise. Cf. D.A. LowriE, Rebellious Prophet: A Life of Nicolai Berdyaev, (London: Harper \& Brothers, 1960), 251.

${ }^{14}$ Cf. R. FICEK, Christians in Socio-Political Life, 44-51.

${ }^{15}$ Such experts on the subject as Raymond Aron, Albert Camus, Ernst Cassirer, Norman Cohn, Waldemar Gurian, Jacob Talmon, and Eric Voegelin emphasize the mythological component of
} 
Contrary to democratic states, the sacralization of politics under totalitarian rule, along with its liturgies, holidays, and cults, is marked by the leader's deification. Moreover, it is characterized by an idolatrous cult of the state which gives itself the exclusive right to determine good and evil; the marginalization or destruction of traditional religion; orgiastic mass rallies; emphasizing the leading role of the political party assigned to the part of "political demiurge"; call to sacrifice and the worship of death. An interpretation of totalitarianism that emphasizes political religion has one important implication. It suggests that totalitarianism should be understood not as much as a specific political system but as a historical "eventuality" that carries particular threats also for the modern world. ${ }^{16}$

It is no wonder then that Cardinal Wyszyński opposed both the totalitarian concept of German Nazism and the Marxist-Leninist materialist ideology and considered them the greatest danger to Christianity. Especially communism, as an ideology that spreads an atheistic-materialistic vision of the human person and social life, it was deemed to be hostile to Christian aspirations promoting respect for human dignity and shaping the Christian social order. Moreover, the materialism embedded in totalitarian systems denies the existence of Christian spirituality. Thus, it is a progressive deviation degenerating the supernatural, spiritual, and religious sphere of human life. Instead, atheistic materialism only recognizes a reality that can only be grasped by sense experience. However, it aims to blind people and thus dissuades them from the supernatural and eternal realm.

\section{CHRISTIAN MORAL-RELIGIOUS PERSPECTIVE VERSUS COMMUNIST TOTALITARIAN IDEOLOGY}

Stefan Wyszyński's teaching and his pastoral activity fall during an incredibly difficult period in the Polish Nation's history. It was threatened both by adverse geopolitical conditions and exposed to various forms of moral deprivation and misery. ${ }^{17}$ However, Cardinal Wyszyński's opposition towards atheistic Communism

totalitarianism. Thus, they mention "substitute religions", "political religions", "myth of the state", "sacralization of politics". In their opinion, political religion is an essential element of totalitarianism as well as a dangerous and lethal weapon in the ideological arsenal of totalitarian systems. Cf. E. GENTILE, "The Sacralization of Politics: Definitions, Interpretations, and Reflections on the Question of Secular Religion and Totalitarianism", Totalitarian Movements and Political Religions (2000), 1,1:41.

${ }^{16}$ Cf. R. FICEK, Christians in Socio-Political Life, 147-150.

${ }^{17}$ Cf. P. Blackledge, Marxism and Ethics: Freedom, Desire, and Revolution (Albany, NY: State University of New York Press, 2012), 19-44. 
was based mainly on Christian tradition and personalism. Referring to the popes' teaching, he states that socialism's fundamental error is an anthropological issue. Analyzing the concepts of this ideology, Wyszyński pointed out: "Man does not have any personal value in their eyes. He is merely nothing. [...] Therefore, firstly, people are denied the rights of a person: freedom, thinking, and acting. Man is subject to unconditional obedience to the supreme power. [...] The human person is subjected to complete contempt, the government system's inexorable hardness, the inhumanity of great lawlessness, despotism, and terror. In practice, citizens are enslaved to the community. Secondly, people are denied the freedom to believe in and worship God. For in man, the eternal principle is not recognized, nor any other destiny other than temporal. Hence the organized, official struggle against religion is a new task of the current state. Hatred organized!". ${ }^{18}$

Additionally, the reduction of man only to his material needs to undermine the legitimacy of all religions. As encapsulated in Marx's boast that Communism abolishes eternal truths, it abolishes all religion and is directly opposed to the faith practice. ${ }^{19}$ "Communism wants to build a world without God. Man wants to be brought up without God's commandments and religious morality, only based on the mass's morality. So you have to destroy all religion. Man is the new god of a man. The highest happiness: proletarian equality. In this way, man, created in God's image and likeness, detached from his Creator, is thrown into the depths of godlessness and mortality. Thirdly, one's destiny and individual goals are rejected. He has no soul and no destiny". ${ }^{20}$

Moreover, "no one can measure man's goal of pursuing happiness in God. Man is obliged to pursue these goals, which the state will show him. He must be socialized, all over his body and soul. He must sacrifice all, fulfill all community orders. Finally, fourthly, a new goal is imposed on man, indicated by collective life. Because spiritual values have no meaning, the purpose of the highest human life will be the good of the state, society, nation, class, party, or economic goal, organized atheistically, temporal, material happiness, and earthly paradise: selfprofit or also through communist profit. In other words, the deification of matter, profit, production, technology. ${ }^{21}$ Beyond the human being - emphasizes the Cardinal - there is no personality, no rationality, and no freedom". ${ }^{22}$

\footnotetext{
${ }^{18}$ S. WYSZYŃSKI, Miłość i sprawiedliwość społeczna. Rozważania społeczne (Poznań: Pallotinum, 1993), 46-47.

${ }^{19}$ Cf. E. Gentile, "The Sacralization of Politics", 48-50.

${ }^{20} \mathrm{~S}$. WYSZYŃSKI, Miłość i sprawiedliwość spoteczna, 47.

${ }^{21}$ Ibidem, 47-48.

${ }^{22}$ Spoteczność przyrodzona i nadprzyrodzona, 61.
} 
Therefore, in a situation where influential and - at the same time - hostile forces had sought to corrupt the Nation, Poland's Primate felt a moral obligation to awaken the Nation's conscience to prepare it for a fight against the damaging effects of social demoralization. "23 "Today, the world is transforming into a sort of stable, where the alchemy of life is limited to the process of eating, and people are left without perspectives, without imaginings and ideals, without emotional tensions, with some strange distrust to the human mind, as if it was not worthy to touch God. Man is deprived of trust in the power of human will, which overcomes itself. It raises distrust of the human heart, which is so important not only in sociology and pedagogy but even in politics". ${ }^{24}$

Nevertheless, the large-scale struggle against religion and the Church also resulted from the specificity of totalitarian power, which sought to deprive a person of a sense of dignity, independent thinking, and, consequently, of freedom itself. ${ }^{25}$ Analyzing the adverse effects of totalitarian propaganda, Cardinal Wyszyński stated: "This spiritual deflation, moral and cultural minimalism led to impudence, which implies determined crackdown on the religious aspirations, needs, feelings, and ambitions of the human person". ${ }^{26}$ Thus, Christian humanism, which proclaims dignity and true human freedom, by its very nature contradicts the spirit of communist totalitarianism.

Therefore, moral renewal has become an indispensable condition for positive changes in Poland. It is realized within the framework of the Church's community, which, preaching the Gospel message of redemption accomplished in Jesus Christ and calling for faithfulness to the grace of baptism, displays the ways and means of renewing all structures of social life in the context of their specific historical reality. ${ }^{27}$ The essence of the Church's mission is also expressed by revealing a thoroughly biblical and theological vision of the human person, emphasizing

23 "List Episkopatu Polski do duchowieństwa o moralnym zagrożeniu narodu. Warszawa 25 I 1968”, in: Listy Pasterskie Episkopatu Polski 1945-1974 (Paris: Editions du Dialogue, 1975), 508; Cf. A. Dudek, A. FriszKe, J. Gowin, W.J. Wysocki, J. ŻARYn, "Komunizm i religia w Polsce - trwanie i zmiana", Pamięć i Sprawiedliwość (2005), 1:35-51.

${ }^{24}$ S. WYSZYŃSKI, “Zwycięstwo wiary naszej. Do duchowieństwa Warszawy 24 XII 1973”, in: Nauczanie społeczne, 570.

${ }^{25}$ Cf. R. ZACHARIAS, The Real Face of Atheism (Grand Rapids: Baker Books, 2004), 20-33.

${ }^{26}$ S. WYSZYŃSKI, "Nowoczesny program ślubowań akademickich. Jasna Góra 4 V 1974", in: Kazania i przemówienia autoryzowane 1956-1981, Archiwum Instytutu Prymasowskiego w Warszawie, vol., XLVI, 7.

${ }^{27}$ Cf. R. FICEK, Christians in Socio-Political Life, 308-311. 
"[...] the splendor of man - a rational and free being, aware of his great responsibility for his own life and the Nation". ${ }^{28}$

It inclines Cardinal Wyszyński to state: "The fundamental mistake is to renew the family, nation, state, or socio-political system without renewing the man himself. One must first recognize that man has the right to his Savior-Renewal, and really in every dimension. This law is significant and irreversible that any attempt to separate man from Christ is, in reality, suicide for the family, nation, and the entire social system". ${ }^{29}$

\section{SYSTEMIC SECULARIZATION AND ATHEIZATION AS AN ORGANIZED MENACE TO THE EXISTENCE OF THE NATION}

The systemic action planned by the atheist state that threatened the fundamental structures of the social and moral life of the Nation was primarily related to the program atheization and secularization, which was also associated with large-scale anti-religious activities. ${ }^{30}$ It resulted from the fact that in post-war Poland, materialism, in a sense, became valid and widely promoted by totalitarian centers of power. This fact was justified by Marxist materialism's philosophical assumptions, which sought to create a secular society totally liberated from "religious alienation". ${ }^{31}$ Primate Wyszyński, together with the Polish Episcopate, warns that "[...] imposed laicization aims to form a man who would be convinced of the validity of the materialistic philosophy and everything that it proclaims. Ultimately, then, it is about spreading a specific type of atheism" ${ }^{32}$

The programmed process of secularization and atheization carried out with the help of various means and methods, therefore, posed a massive threat to

\footnotetext{
${ }^{28}$ S. WYSZYŃSKI, "Duch Ewangelii w organizacji życia społeczno-zawodowego i publicznego w Polsce. Do wiernych w archikatedrze warszawskiej 6 I 1978”, in: Nauczanie społeczne, 808.

${ }^{29}$ IDEM. "Przemówienie w Boże Narodzenie w archikatedrze św. Jana Chrzciciela. Warszawa, 25 XII 1978”, in: F. KNIOTEK (red.), Prymas Tysiaclecia (Paryż: Edition dialogue, 1982), 274.

${ }^{30}$ Cf. IDEM., "O zagrożeniu moralności narodu. List pasterski na wielki post 1968", in: Nauczanie społeczne, 343-344; "Apel Synodu w obronie praw człowieka. Po powrocie z Synodu Biskupów, Warszawa 26 I 1975”, in: Nauczanie społeczne, 619-626; "Problemy życia społecznego w Polsce. Do duszpasterzy młodzieży męskiej 29 XII 1975”, in: Nauczanie społeczne, 669-672.

${ }^{31}$ Cf. P. BlackLEDGE, Marxism and Ethics: Freedom, Desire, and Revolution (Albany, NY: State University of New York Press, 2012), 49-57.

32 „List Episkopatu Polski o laicyzacji. Warszawa 22 III 1968”, in: Listy Pasterskie Episkopatu Polski 1945-1974, 522.
} 
both native cultures as well as to the religious and moral life of the Nation. ${ }^{33}$ Aware of the seriousness of the situation, Primate Wyszyński emphasizes: the Church warns the nation against the consequences of forced atheization, against the breakdown of the religious and moral unity of society, against the inevitable nihilism that breeds ideological emptiness and negation of all spiritual values. ${ }^{34}$

The adverse effects of secularization and atheization on the moral life have a very destructive impact, especially on the Christian model of marriage and the family, causing their demoralization and, consequently, its decay. ${ }^{35}$ At the root of this phenomenon is the distortion of the very understanding of marriage and the family, which brings them to "institutions of use, liberation from ethical norms, from responsibility, and burdens". ${ }^{36}$ It is expressed not only in the false vision of love - reduced only to shallow feelings or sex drive - but it is also a severe distortion of the truth about man and his fundamental call to love.

A very significant threat, directly threatening the biological structures of the nation's life, was associated with the anti-population policy of the state. Thanks to the law allowing the termination of pregnancy and large-scale anti-natalist propaganda, a terrible manipulation of Polish society was carried out. Among the significant part of it, as Primate Wyszyński emphasized: "There is a mistaken belief that a child in the womb is not yet a human being and, as such, is deprived of all rights". ${ }^{37}$ The anti-population policy of the state has also made negative changes in social mentality. "Society was infected with an unprecedented fear of reproduction. Childhood was considered almost anti-social. The spouses began to renounce more offspring not only because of difficult living conditions but more often for fear of condemning public opinion". ${ }^{38}$

\footnotetext{
${ }^{33}$ Cf. A. Dudek, A. FriszKe, J. Gowin, W.J. Wysocki, J. ŻARYN, "Komunizm i religia w Polsce", 39-44.

${ }^{34} \mathrm{~S}$. WYSZYŃSKI, "List wielkopostny do duchowieństwa i wiernych o zagrożeniu moralności narodu. Gniezno-Warszawa 2 II 1968”, in: Listy Pasterskie Episkopatu Polski 1945-1974, 572.

${ }^{35}$ Cf. R. FiCEK, Christians in Socio-Political Life, 45-49.

36 “Orędzie Episkopatu Polski w sprawie małżeńskiej. Jasna Góra, 7.12.1945”, in: Listy Pasterskie Episkopatu Polski 1945-1974, 25.

37 "Głos biskupów polskich w obronie zagrożonego bytu Narodu. 4. IX 1970”, in: Listy Pasterskie Episkopatu Polski 1945-1974, 625.

${ }^{38}$ Ibidem, 624. In common crimes of infanticide committed in Poland "in the majesty of the law" Primate saw the causes of biological and moral degradation threatening the Polish Nation. (cf. "Memoriał Episkopatu Polski do rządu PRL w sprawie zagrożeń biologicznych i moralnych Narodu Polskiego. (1970)", in: S. WYSZYŃSKI, Prymas Polski w obronie życia nienarodzonych [Warszawa: ODiSS, 1982, cz. II], 306). For this reason, he consistently demanded the introduction of a total ban on the murder of unborn children who have the same right to life and development as those born. Therefore, they should enjoy absolute legal protection from the moment of their conception.
} 
Challenging all authorities and undermining fundamental moral principles entails a severe threat of demoralization of society, particularly the young generation. Completing such attitudes as agreeableness towards evil, the mockery of value, egoism and comfort, consumerist attitudes towards life, lust, fornication, drunkenness, and drug addiction become a real manifestation. ${ }^{39}$ In this sense, it causes a universal moral crisis associated with a weakening of faith. It also contributes to the degeneration of the system of fundamental moral values and thus directly harms the biological and cultural foundations of the Nation's existence. ${ }^{40}$

These facts are particularly evident in the social scourge of alcoholism and hedonistic lifestyles. They affect specific people, degenerating them not only biologically and spiritually but also destructively affecting family, Nation, and all structures of social life. By embracing a vast group of addicts, alcohol abuse harms both the economic and socio-political sphere, as well as degrades the mental and spiritual dimension of the polish social life. ${ }^{41}$ The disappearance of the attitude of responsibility, as well as the degeneration of family, professional and national consciousness, is, in turn, the basis for the growth of various types of social pathology: sexual promiscuity, related diseases, increase in crime, acts of vandalism and hooliganism, road accidents while intoxicated and other social problems. In this context, dishonesty, envy, and alcoholism appear as a severe danger to society's moral and spiritual life, which requires special stigmatization and constructive responses. ${ }^{42}$

Characterizing the moral situation of Polish society, Primate Wyszyński pointed out: "Our moral weakness and instability, despite our strong faith, our moral relativism, willing to succumb to bad examples and currents, paying

In a memorial addressed to the government of the Polish People's Republic in 1970, together with the entire Episcopate, he sharply stigmatized existing legislation and practices in the field of protecting unborn children. Referring to international law, he denotes to the Declaration of the Rights of the Child adopted unanimously on November 20, 1959, by the UN General Assembly and to the "International Covenant on Civil and Political Rights" adopted by the UN General Assembly on December 16, 1966, which clearly state that every human being has the inherent right to life. This right should be protected by law, and no one can be arbitrarily deprived of life. (cf. „Memoriał Episkopatu Polski do rządu PRL w sprawie zagrożeń biologicznych i moralnych Narodu Polskiego", 305-306).

${ }^{39}$ Cf. IDEM, "To jest nasz program prymasowski. Do wiernych w bazylice prymasowskiej w Gnieźnie 2 II 1957”, in: Nauczanie społeczne, 75-76; “Nasze dezyderaty. Do profesorów katolickiej nauki społecznej, Jasna Góra 22 I 1963", in: Nauczanie społeczne, 198-200; "O zagrożeniu moralności narodu. List pasterski na wielki post 1968”, in: Nauczanie spoteczne, 343-348.

${ }^{40}$ Cf. R. FICEK, Christians in Socio-Political Life, 309-312.

${ }^{41}$ Cf. S. WysZYŃskI, "Jakiej chcecie Polski? Do młodzieży akademickiej w Warszawie 22 III 1972", in: Nauczanie spoteczne, 491-492; "Ratujmy życie w rodzinie. List pasterski na XXXIV Tydzień Miłosierdzia 26 VII 1978”, in: Nauczanie społeczne, 843-844.

${ }^{42}$ Cf. R. FICEK, Christians in Socio-Political Life, 313. 
attention to various errors, sometimes absurd, the collapse of marital morality, infidelity, promiscuity, and drunkenness. All of these make the social division so shaky. We can last for hours in temples, stand on Jasna Góra square, like old oak wood, but we easily succumb to even the weakest excitement to all sins and vices. We are spiritually split, mentally broken, and, therefore, deprived of a lifestyle and national character". ${ }^{43}$

Many destructive threats to social life were additionally stimulated by a programmed process of inciting and fueling selfishness and social hatred. "It is significant - says Wyszyński - that in the aspirations for the proletariat's liberation, a lot of room is occupied by religious and moral matters or the fight against the Christian religious worldview". 45 As erroneous doctrinal assumptions, hatred is recognized as a motor force of the Communist "progress", applying the principle of "divide et impera". The Christian spirit of forgiveness and peace is declared war in the name of alleged justice, and primarily in the name of pagan hatred" ${ }^{46}$ In this context, the spread of egoism and social hatred appears as a severe distortion of spiritual and moral culture, which harms both the dignity of the human person and the unity of the Nation.

Therefore, programmatic hatred, destruction of love understood as the basis of unity, became a dangerous threat to both the human person and family as well as to the nation, which, broken and internally divided, is deprived of future prospects. "The illusion that raises many misfortunes for peoples and nations is the belief that one can build on unbelief, atheism, and class struggle, while - in reality - our world can be created only through brotherly mutual love. If today's world needs something, it is faith that we come from God who is Love and does everything in love: from God who first loved each of us" ${ }^{47}$

As a result, emphasizing the fundamental threats to social life, focused primarily around basic religious values, becomes an essential dimension in the teaching of the Primate of Poland. His goal was not, however, the theoretical analysis of the problems but shaping the moral awareness of Polish society. Therefore, the pastoral teaching of Cardinal Wyszyński becomes a unique expression of the prophetic mission of the Church and - also in our contemporary times - is a call to conversion and moral renewal of both a particular man and the entire Nation.

\footnotetext{
43 "List Episkopatu Polski do duchowieństwa o moralnym zagrożeniu narodu. Warszawa 25 I 1968”, in: Listy Pasterskie Episkopatu Polski 1945-1974, 508.

${ }^{44}$ Cf. R. ZACHARIAS, The Real Face of Atheism, 48-59.

${ }^{45}$ S. WySZYŃSKI, Miłość i sprawiedliwość spoteczna, 103.

46 “List Episkopatu Polski do duchowieństwa o moralnym zagrożeniu narodu”, 507.

47 "Dobrzy bracia. Podczas uroczystości 250 rocznicy przybycia bonifratrów do Warszawy 26 IX 1976”, in: Nauczanie spoteczne, 748.
} 


\section{PRIMATE'S PASTORAL PROGRAM: TOWARDS THE SOCIO-MORAL RENEWAL}

The far-reaching idea of healing the entire reality of social life is carried out by the Primate Wyszyński in his concept of moral and spiritual renewal, which was mainly expressed in the program of the "Jasna Gora Vows" preceding the "Great Novena" which had been preparing the Nation for the jubilee of the Millennium of the Baptism of Poland. The very fact of vows at Jasna Góra was an enormous event in the Church and the nation's life. Based on faith in God's Providence and on commitments to work on individuals, families, and society's moral and spiritual transformation - despite their religious nature - they defended man and the entire Nation. ${ }^{48}$

The program of the Great Novena constituted a closed and well-prepared entirety. It started from the issue of loyalty to God and the Church - which placed man in God's plan of salvation and expressed a fundamental relationship with God. Faithfulness over here meant both a moral category - keeping God's law - and an ontological principle: coexistence with God. ${ }^{49}$ Therefore, man's relationship with God understood in this way was similar to the Paradise covenant situation. Thus, the Primate's intention was not only the moral improvement of the Nation but also its new form of existence - as a people of God in the image of Israel. ${ }^{50}$

In this regard, man - both in the individual and social dimension - is the path for both the Church and moral renewal. The religious and moral order rooted in the human person is a condition for man's individual renewal. Still, due to this, the reform of all social life structures is also implemented ${ }^{51}$. Therefore, the concept of moral regeneration in the teaching of Primate Wyszyński is not individualistic. Family order must be connected with the order of the heart of every Polish inhabitant because social order is built in the family. An entire national organism is created there because the nation consists of families. ${ }^{52}$ Also, "[...] state life must be conditioned by the order and calmness of national

\footnotetext{
${ }^{48}$ Cf. M. Wóscıк, "Religijna odnowa Narodu w Jasnogórskich Ślubach Ks. Prymasa Stefana Kardynała Wyszyńskiego", Studia nad Rodzina (2006), 10, 1-2:259-278.

${ }^{49}$ Cf. R. ŁATKA, J. MARECKI, Kościót katolicki w Polsce rządzonej przez komunistów (Warszawa: IPN, 2017), 67-69.

${ }^{50}$ Cf. S. WYSZYŃSKI, "Dobrzy bracia”, 748.

${ }^{51}$ Cf. S. WYSZYŃSKI, "Nie dać sobie wydrzeć ziemi! Do Solidarności wiejskiej rolników indywidualnych. Warszawa-Miodowa 2.04.1981”, in: IDEM, Kościót w stużbie narodu (Rome: Corda Cordi, 1981), 269-230.

${ }^{52}$ S. WYSZYŃSKI, "Patron Polski i mąż stanu. Podczas uroczystości świętego Stanisława w Krakowie 14 V 1978”, in: Nauczanie spoteczne, 830.
} 
life, which depends on the peace and order of family life, which in turn depends on the order of the heart. ${ }^{53}$

The issue of Christian morality extends to all areas of human life.$^{54}$ In the context of mutual determinants of complex structures of human life, one can speak of the social dimension of moral renewal, which becomes the reverse of the social dimension of sin. However, moral renewal takes place " $[\ldots]$ in the community of the Church, in which responsibility for received faith and experience of love is born. Responsibility for the faith and love of others is also carried. Through faith and love, we become able to confess Christ to people and social love". ${ }^{5}$

Thus, the foundation of social life's moral renewal is the revival in Christ realized through metanoia and reconciliation with God. However, it requires a radical turn towards God, which results in the transformation of consciences and the deepening of awareness and moral sensitivity of the human person, family, and the Nation. A change in the way of thinking and esteeming the Christian values results in a shift in attitudes that lead to holiness and lead to Christian perfection in Christ. ${ }^{56}$ Moreover, "the Church is an ally of the Nation and proclaims the principles of the Gospel and sound Christian morality when it awakens love for God and social love when it continually maintains moral sensitivity, awakening a sense of social, professional, cultural, scientific duty when it always reminds us all that a nation's life and development are not possible without the spirit of sacrifice and fraternal service". ${ }^{57}$

However, the condition for the moral transformation of the whole social reality becomes an integral human renewal, not a one-off act, but a permanent attitude aimed at breaking with evil, practicing Christian virtues, and cultivating supernatural life. Referring to the issue of moral renewal of the Nation, Primate Wyszyński states: "It is necessary to start with the repair of man". ${ }^{58}$ Therefore, it is impossible to form the virtues and moral goods both in the individual and community dimension, without a fundamental change in the way of thinking

\footnotetext{
${ }^{53}$ Ibidem.

54 "Duch Ewangelii w organizacji życia społeczno-zawodowego i publicznego w Polsce. Do wiernych w archikatedrze warszawskiej 6 I 1978”, in: Nauczanie społeczne, 807.

55 "Jakiej chcecie Polski? Do młodzieży akademickiej w Warszawie 22.03.1972”, in: Nauczanie spoteczne, 490.

${ }^{56}$ Cf. R. FICEK, Christians in Socio-Political Life, 315-317.

${ }^{57}$ S. WYSZYŃSKI, "Kościół nie walczy z władzą, tylko z jej nadużyciami. Podczas uroczystości Świętego Stanisława w Krakowie 11 V 1975”, in: Nauczanie spoteczne, 646.

58 “O moralną odnowę Narodu. Do wiernych w bazylice gnieźnieńskiej 2 II 1981”, in: Nauczanie spoteczne, 1007.
} 
and values, i.e., the proper formation of the conscience of the human person - and hence, of all social reality - in the spirit of the authentically biblical truth of Christ.

Consequently, the tragic experiences of the past demand an attitude of vigilance. Especially that, as the Primate pointed out, "[...] no one in the world is sure about the future. No 'golden age' can be guaranteed to any nation. And we also have no guarantee that Poland will not have to make sacrifices, and really serious!" ${ }^{59}$ The significance of the threats is added because Poland's post-war situation was not conducive to the Nation's moral renewal.

Moreover, it can be stated that ideological and socio-political conditions arising after the war contributed to the intensification of the moral threats to the Nation's life. That is why Primate Wyszyński, emphasizing this problem, considers it essential and even decisive for creating a Christian society. "It is easy to pour all the nation's wealth into the depths, but the great challenge is to lead a boat in a storm to save everything that is in it." 60

According to Cardinal Wyszynski, particularly dangerous threats, which undermine the very core of social life, are processes aimed at uprooting a Nation from its cultural heritage. They are expressed not only in strenuous efforts to break with the historical past but also with an attempt to create their own fake vision of history, culture, and morality, in line with the Marxist-materialist model. Conscious and intentional falsification of the Nation's historical past, diminishing its value for the modern generation, resulted in the Nation's inevitable cultural eradication. The loss of self-identification on the cultural level obviously has very destructive consequences that could have led the nation to complete disintegration. ${ }^{61}$

Thus, man redeemed in the paschal mystery by Jesus Christ demands in his concrete existence subsequent acts of liberation from his current state of $\sin$. The work of freedom takes place on the level of conscience. Therefore, a free person decides for himself about the value of his commitment, freeing it from destructive systems of depersonalization and enslavement.

Responsibility for evil and sin, having a personal character, also expresses the social aspect; it becomes collective complicity in the misappropriation of moral values and principles that flows from God's law. Though, Primate Wyszyński warns against shifting the burden of responsibility beyond particular human

\footnotetext{
59 "Bez ofiar i wyrzeczeń nie ma zwycięstwa. Warszawa - kościół Matki Bożej Zwycięskiej 16 VIII 1970”, in: IDEM, Z gniazda orląt, 102.

60 “Sursum corda. Z kazania do górali tatrzańskich. Zakopane 1957”, in: IDEM, Wszystko postawitem na Maryję (Paris: Editions du Dialogue, 1980), 145.

${ }^{61}$ Cf. J.B. Metz, A Passion for God: The Mystical-Political Dimension of Christianity (NJ: Paulist Press, Mahwah, 2008), 36-49.
} 
conscience. Although man's moral consciousness was severely deformed as a result of relativization of concepts and values as well as blunting of society's moral sensitivity, any form of degradation, deformation of feelings, or social demoralization required active cooperation and involvement of specific people. ${ }^{62}$

Therefore, the essential condition for moral renewal becomes the "awakening of conscience", which for a Christian is the most secret center and sanctuary where he/she stays alone with God. In his speech to the faithful in Ołtarzew, the Cardinal emphasized: "In every person, in every family, in every word of truth, in the life of the Nation and the State, personal conscience, social conscience, professional conscience, as well as economic conscience and political conscience must wake up" ${ }^{63}$ Only the man of "awakened conscience" - that is, the one in which the most profound and most complete work of spiritual liberation was accomplished, is the foundation for building the whole of renewed socio-political reality. The realization of this desire is possible only on the path of conversion to God in a spirit of faith, realizing one's sinfulness, and undertaking the effort of fulfilling the call to holiness. ${ }^{64}$

According to Cardinal Wyszyński, an essential role in the entire process of social life's renewal is performed by the religious and moral order that underlies every human person's spiritual transformation. It enables integral formation, covering the human person's full dimension - and hence the family, the nation, and the entire reality of social life. At the end of his pastoral activity, Cardinal Wyszyński stated: "It is about man! For a better man, for a good man, and for such a man who would be aware of the responsibility for his own life, for the life of his family and the whole nation. We need to be mindful of the responsibility [...] for one's own life so that it would be useful both personally, in family life, in professional life as well as in national, native, and even political life". ${ }^{65}$

Thus, the fruit of full moral renewal of social life's entire reality is a mature attitude towards moral life threats. It requires strong opposition not only to those dangers that resulted from geopolitical conditions and systemic degenerations of the socio-political system of post-war Poland. A significant challenge for

\footnotetext{
${ }^{62}$ Cf. "Apel Prymasa Polski ze stolicy do wszystkich Dzieci wspólnej Ojczyzny. Warszawa, 25 XII 1970”, in: Prymat człowieka w tadzie społecznym, (Londyn: Odnowa, 1976), 17-18; IDEM, Sumienie w petnieniu obowiazków społecznych. Nadarzyn, 21 IX 1980, in: IDEM, „Praca a godność człowieka" (Częstochowa: Prymasowski Instytut Ślubów Narodu na Jasnej Górze, 1983), 67-73.

${ }^{63}$ IDEM, W godzinie wielkiego rachunku sumienia. Ołtarzew 2 X 1980, in: Kościót w stużbie narodu, 73.

${ }^{64}$ Cf. J. B. MetZ, A Passion for God, 136-147.

65 “"Zło dobrem zwyciężaj. Do „Solidarności“ z Gdyni. Warszawa, Kaplica Domu Prymasowskiego, 22 II 1981”, in: IDEM, Do „Solidarności“. Rady i wskazania (Warszawa: Soli Deo, 1996), 66-67.
} 
the entire nation is the fight against moral defects destabilizing social life, breaking down its essential structures, leading to general anarchy, and, consequently, the state's destruction. "Therefore, in defense of moral freedom against the captivity of addictions, we want to use all religious, social, and cultural forces that can serve our vigor and spiritual freedom, which in turn depends on all other freedom - political or economic. There will be no change for the better in our hearts, nor social and state life unless we open the door to Christ" ${ }^{66}$ Return to Christ thus becomes the basis for the moral renewal of the whole reality of social life. It takes place both on the path of continuous transformation, converting the heart and attitudes of individual people and the entire community, as well as on the way of sacramental reconciliation with God in the Church. ${ }^{67}$

Nevertheless, an essential dimension of moral renewal in the understanding of Primate Wyszyński is a distinct Marian feature. Emphasizing Mary's role in the work of moral renewal carries out its theological, psychological, and sociological justification. It is true that "I have put everything on Mary," and I am faithful to it. It is born of a deep conviction that in our homeland, the creation and maintenance of a religious community must be done in a dimension to which people are most sensitive. With us, this is done through the mediation of the Holy Mother of God". ${ }^{6}$

\section{CONCLUSIONS}

After the death of Cardinal Wyszyński, the Polish Episcopate, assessing the value of the Marian pastoral program of the Primate, stated: "Today, in retrospect, we can see that the genius of the Marian way of the Primate of Poland was that he was able to bring the Mother of God from the glory of the altars into the everyday life of the Nation. He appealed to the living presence of Mary in the Church. He introduced her to the whole painful reality of the people entrusted to him". ${ }^{69}$

In the developed teaching about Mary as the Mother of the Church, her unique presence in the salvific work accomplished by Christ was emphasized and

\footnotetext{
66 "Nawróćcie się do Pana", in: Nauczanie społeczne, 488.

${ }^{67}$ Cf. P. KoRNAFEL, Odnowa moralna narodu polskiego $w$ świetle listów pasterskich Episkopatu Polski w latach 1945-1981 (mps.), Biblioteka KUL (Lublin, 1995), 94-95.

${ }^{68} \mathrm{~S}$. WYSZYŃSKI, "Z przemówienia do duchowieństwa diecezjalnego i zakonnego zgromadzonego, aby złożyć życzenia imieninowe ks. kard. Stefanowi Wyszyńskiemu. Warszawa 2 VIII 1980”, in: Prymas Tysiąclecia, 105.

69 "List Episkopatu Polski przed Uroczystością Matki Bożej Jasnogórskiej”, in: Listy Pasterskie Episkopatu Polski 1945-1974, 499.
} 
continuously present in the sacramental reality of the Church's community. Mary, being the "path to Christ", thus becomes an excellent opportunity for religious revival as well as moral renewal of the Polish Nation, so eager for genuine goodness and maternal love. ${ }^{70}$ Therefore, the faithful people have the opportunity to become more fully and actively involved in the life of the Church and her mission addressed to the Nation as well as the entire world.

Nevertheless, the Church manifests herself above all as the "sacrament of salvation." By revealing Christ to the modern world, she proclaims her message and the reviving powers of grace from the perspective of the universal call to holiness. In this context, the unique character of Cardinal Wyszyński's mission was expressed both in ordinary pastoral work - consisting mainly in organized catechetical and liturgical and sacramental service - as well as in extraordinary devout effort, which took the form of the "Marian way" of moral renewal. Therefore, in the Polish social and political reality, the Church became a fundamental source of moral renewal of the human person in his full dimension, which she implemented "[...] demanding that man is an indeed child of God, that the splendor of man - a rational and free being, aware of his great responsibility for his own and the nation's life - would be revealed". ${ }^{71}$

Though, the primary condition enabling the Church to fulfill her salvific mission towards man, family, nation, and the whole reality of social life is to ensure an appropriate climate of freedom of action. Aware of the difficult socio-political situation, Cardinal Wyszynski stated: "The minimum that we can make as a postulate in this reality is included in the fact that the state should act "ad bonum commune totius universi" [...]. That is why we expect the state community to serve the universal good of the entire diverse population of citizens of our fatherland" ${ }^{72}$

\section{BIBLIOGRAPHY}

Albert, M., Hahnel, R., Socialism Today and Tomorrow. Boston, Massachusetts: South End Press, 1981.

BARTNIK, Cz. Kultura i świat osoby. Lublin: STANDRUK, 1999.

Bierdiajew, N. "Marksizm, czyli fałszywa religia". In: M. BANKowiCz (red). Krytycy marksizmu, 43-52. Kraków: Wydawnictwo Uniwersytetu Jagiellońskiego, 2014.

\footnotetext{
${ }^{70}$ Cf. Cz. BARTNIK, Kultura i świat osoby (Lublin: STANDRUK, 1999), 485-488; P. KoRNAFEL, Odnowa moralna, 216.

${ }^{71}$ S. WYSZYŃSKI, "Duch Ewangelii w organizacji życia społeczno-zawodowego i publicznego w Polsce. Do wiernych w archikatedrze warszawskiej 6 I 1978”, in: Nauczanie społeczne, 808.

${ }^{72}$ Naród-Kościół-Państwo. Kazanie świętokrzyskie 25 I 1976, in: Nauczanie społeczne, 711.
} 
Blackledge, P. Marxism and Ethics: Freedom, Desire, and Revolution. Albany, NY: State University of New York Press, 2012.

BochEŃSKI, J.M. NieMEYeR, G. Handbuch des Weltkommunismus. Fribourg-München: Alber, 1958.

BOROWSKI, A. "Social interactions in the public space in the context of public confidence". International Letters of Social and Humanistic Sciences (2014), 25:33-41.

Dudek, A., Friszke, A., Gowin, J., Wysocki, W.J., ŻARYN, J. “Komunizm i religia w Polsce - trwanie i zmiana". Pamięć i Sprawiedliwość (2005), 1:35-51.

FICEK, R. Christians in Socio-Political Life: An Applied Analysis of the Theological Anthropology of Cardinal Stefan Wyszyński. Toruń: Marszałek, 2020.

Gentile E. "The Sacralization of Politics: Definitions, Interpretations, and Reflections on the Question of Secular Religion and Totalitarianism". Totalitarian Movements and Political Religions (2000), 1,1:18-55.

Gtos biskupów polskich w obronie zagrożonego bytu Narodu. 4 IX 1970. In: Listy Pasterskie Episkopatu Polski 1945-1974, 620-629. Paris: Editions du Dialogue, 1975.

Kershaw, I. Lewin, M. Stalinism and Nazism: Dictatorships in Comparison. Cambridge, U.K.: Cambridge University Press, 1997.

KoRnAfel, P. Odnowa moralna narodu polskiego w świetle listów pasterskich Episkopatu Polski w latach 1945-1981 (mps.). Lublin: Biblioteka KUL, 1995.

"List Episkopatu Polski do duchowieństwa o moralnym zagrożeniu narodu. Warszawa 25 I 1968." In: Listy Pasterskie Episkopatu Polski 1945-1974, 501-509. Paris: Editions du Dialogue, 1975.

“List Episkopatu Polski o laicyzacji. Warszawa 22 III 1968”, In: Listy Pasterskie Episkopatu Polski 1945-1974, 521-528.

“List Episkopatu Polski przed Uroczystością Matki Bożej Jasnogórskiej”. In: Listy Pasterskie Episkopatu Polski 1945-1974, 498-507.

Lowrie, D.A. Rebellious Prophet: A Life of Nicolai Berdyaev. London: Harper \& Brothers, 1960.

ŁATKA, R., MARECKI, J. Kościót katolicki w Polsce rządzonej przez komunistów. Warszawa: IPN, 2017.

Macintyre, A.C. Marxism and Christianity. New York: University of Notre Dame Press, 1984.

"Memoriał Episkopatu Polski do rządu PRL w sprawie zagrożeń biologicznych i moralnych Narodu Polskiego. (1970).” In: S. WYSZYŃSKI. Prymas Polski w obronie życia nienarodzonych, cz. II, 302-309. Warszawa: ODiSS, 1982.

Metz, J.B. A Passion for God: The Mystical-Political Dimension of Christianity. Mahwah, NJ: Paulist Press, 2008.

“Orędzie Episkopatu Polski w sprawie małżeńskiej. Jasna Góra, 7.12.1945”. In: Listy Pasterskie Episkopatu Polski 1945-1974, 22-30.

Perlmutter, A. Modern Authoritarianism. A Comparative Institutional Analysis, Conn: Yale University Press, New Haven, 1981.

Strojny, J. Obraz Kościoła w przepowiadaniu i piśmiennictwie Stefana Kardynała Wyszyńskiego. Warszawa, 1984.

WóJCıK, M. "Religijna odnowa Narodu w Jasnogórskich Ślubach Ks. Prymasa Stefana Kardynała Wyszyńskiego”. Studia nad Rodzina (2006),10,1-2:259-278.

WysZYŃSKI, S. “Apel Prymasa Polski ze stolicy do wszystkich Dzieci wspólnej Ojczyzny. Warszawa, 25 XII 1970”. In: IDEM. Prymat człowieka w tadzie społecznym, 15-19. Londyn: Odnowa, 1976. 
WYSZYŃSKI, S. "Bez ofiar i wyrzeczeń nie ma zwycięstwa. Warszawa - kościół Matki Bożej Zwycięskiej 16.08.1970”. In: iDEM. Z gniazda orląt, 101-109. Rome: Papieski Instytut Studiów Kościelnych, 1972.

Wyszyński, S. "Czas to miłość. Podczas uroczystości Wniebowzięcia Matki Bożej (Jasna Góra, 15.08.1979)”. In: Nauczanie społeczne 1946-1981, 889-891. Warszawa: ODISS, 1990.

WYSZYŃSKI, S. "Dobrzy bracia. Podczas uroczystości 250 rocznicy przybycia bonifratrów do Warszawy 26. 09. 1976”. In: iDEM. Nauczanie społeczne 1946-1981, 747-751. Warszawa: ODISS, 1990.

WYSZYŃSKI, S. "Duch Ewangelii w organizacji życia społeczno-zawodowego i publicznego w Polsce. Do wiernych w archikatedrze warszawskiej 6.01.1978”. In: Nauczanie społeczne 1946-1981, 801-809.

WYSZYŃSKI, S. “Jakiej chcecie Polski? Do młodzieży akademickiej w Warszawie 22.03.1972”. In: Nauczanie społeczne 1946-1981, 488-493.

WYSZYŃSKI, S. "Kościół nie walczy z władzą, tylko z jej nadużyciami. Podczas uroczystości Świętego Stanisława w Krakowie 11 V 1975. In: Nauczanie spoteczne 1946-1981, 642-647.

WySZYŃSKI, S. "List wielkopostny do duchowieństwa i wiernych o zagrożeniu moralności narodu. Gniezno-Warszawa 2 II 1968”. In: Listy Pasterskie Episkopatu Polski 1945-1974, 469-475.

WYSZYŃSKI, S. Miłość i sprawiedliwość spoteczna. Rozważania społeczne. Poznań: Pallotinum, 1993.

WysZYŃSKI, S. "Naród-Kościół-Państwo. Kazanie świętokrzyskie 25.01.1976”. In: Nauczanie spoteczne 1946-1981, 705-713.

WYSZYŃSKI, S. "Nasze dezyderaty. Do profesorów katolickiej nauki społecznej. Jasna Góra 22.01.1963”. In: Nauczanie spoteczne 1946-1981, 195-200.

WysZYŃSKI, S. “Nawróćcie się do Pana”. In: Listy Pasterskie Prymasa Polski 1946-1974, 486-490.

WYSZYŃSKI, S. "Nie dać sobie wydrzeć ziemi! Do Solidarności wiejskiej rolników indywidualnych. Warszawa-Miodowa 2.04.1981”. In: iDEM. Kościót w stużbie narodu, 268-278. Corda Cordi, Rome 1981.

WYSZYŃSKI, S. “Nowoczesny program ślubowań akademickich. Jasna Góra 4 V 1974”. In: Kazania i przemówienia autoryzowane 1956-1981, vol., XLVI, 24-36. Archiwum Instytutu Prymasowskiego w Warszawie, 1974.

WYSZYŃSKI, S. “O moralną odnowę Narodu. Do wiernych w bazylice gnieźnieńskiej 2 II 1981”. In: Nauczanie społeczne 1946-1981, 1005-1011.

WYSZYŃSKI, S. “O zagrożeniu moralności narodu. List pasterski na wielki post 1968”. In: Nauczanie spoteczne 1946-1981, 343-352.

WYSZYŃSKI, S. "Patron Polski i mąż stanu. Podczas uroczystości świętego Stanisława w Krakowie 14 V 1978”. In: Nauczanie społeczne 1946-1981, 829-835.

WYSZYŃSKI. S. "Problem pracy górników w Polsce. List do księdza biskupa Herberta Bednorza 2.02.1978". In: Nauczanie spoteczne, 810-811.

WysZYŃSKI, S. "Problemy życia społecznego w Polsce. Do duszpasterzy młodzieży męskiej 29 XII 1975”. In: Nauczanie społeczne 1946-1981, 669-675.

WYSZYŃSKI, S. "Przemówienie w Boże Narodzenie w archikatedrze św. Jana Chrzciciela. Warszawa, 25 XII 1978”. In: F. KNIOTEK (red.). Prymas Tysiaclecia, 274-277. Paryż: Edition du Dialogue, 1982.

WyszyŃSKI, S. "Przywódca ludu rolniczego. Poświęcenie tablicy ku czci Wincentego Witosa. Warszawa 28.12.1975”. In: IDEM. „Nie rzucim ziemi...” Z przemówień do rolników, 19-30. Warszawa: Wydawnictwo ATK, 1984. 
WYSZYŃSKI, S. "Ratujmy życie w rodzinie. List pasterski na XXXIV Tydzień Miłosierdzia 26 VII 1978”. In: Nauczanie spoteczne 1946-1981, 840-846.

WYSZYŃSKI, S. "Sumienie w pełnieniu obowiązków społecznych. Nadarzyn, 21 IX 1980”. In: Praca a godność człowieka, 67-73. Częstochowa: Prymasowski Instytut Ślubów Narodu na Jasnej Górze, 1983.

WYSZYŃSKI, S. "Sursum corda. Z kazania do górali tatrzańskich. Zakopane 1957”. In: IDEM. Wszystko postawitem na Maryje, 142-148. Paris: Editions du Dialogue, 1980.

WYSZYŃSKI, S. “To jest nasz program prymasowski. Do wiernych w bazylice prymasowskiej w Gnieźnie 2 II 1957”. In: Nauczanie spoteczne 1946-1981, 74-77.

WYSZYŃSKI, S. “W godzinie wielkiego rachunku sumienia. Ołtarzew 2 X 1980”. In: Kościót w stużbie narodu, 73-77.

WYSZYŃSKI, S. "Z przemówienia do duchowieństwa diecezjalnego i zakonnego zgromadzonego, aby złożyć życzenia imieninowe ks. kard. Stefanowi Wyszyńskiemu. Warszawa 2. VIII 1980”. In: Prymas Tysiąclecia, 103-107.

WYSZYŃski, S. “Zło dobrem zwyciężaj. Do „Solidarności“ z Gdyni. Warszawa, Kaplica Domu Prymasowskiego, 22 II 1981”. In: iDEM. Do „Solidarności“. Rady i wskazania, 63-70. Warszawa: Soli Deo, 1996.

WYSZYŃSKI, S. “Zwycięstwo wiary naszej. Do duchowieństwa Warszawy 24 XII 1973”. In: Nauczanie spoteczne 1946-1981, 570-573.

ZaCharias, R. The Real Face of Atheism. Grand Rapids: Baker Books, 2004.

\author{
ODNOWA MORALNA JAKO IMPERATYW SPOŁECZNO-RELIGIJNY WOBEC \\ DESTRUKTYWNYCH DZIAŁAŃ TOTALITARNEGO PAŃSTWA OPRESYJNEGO: \\ W KONTEKŚCIE PERSONALISTYCZNEJ KONCEPCJI ŻYCIA SPOŁECZNEGO \\ KARDYNAEA STEFANA WYSZYŃSKIEGO
}

\title{
STRESZCZENIE
}

Historyczna spuścizna i destruktywne działania totalitarnego państwa opresyjnego PRL-u wiązały się z poważnymi zagrożeniami życia społeczno-kulturowego Narodu. Powaga sytuacji łączyła się $\mathrm{w}$ tym kontekście zarówno z uwarunkowaniami geopolitycznymi, jak również z szeregiem niedomogów systemowych państwa komunistycznego ideologicznie wrogiego wobec chrześcijaństwa, jak również rodzimej kultury. Istotną jednak rolę odgrywały także niebezpieczne nałogi i narodowe wady moralne. Specyfika sytuacji domagała się zatem bezwzględnego przeciwstawienia się powyższym problemom ze strony wszystkich struktur społecznych Narodu. Zdaniem Kardynała Wyszyńskiego nie chodziło tu jedynie o przezwyciężenie takiej czy innej wady narodowej, ale wymagana była całościowa przemiana moralna w duchu kultury chrześcijańskiej, która mogłaby stać się religijno-społecznym programem moralnego odrodzenia Narodu.

Odnowa moralna stała się zatem nieodzownym warunkiem pozytywnych przemian w Polsce. Realizuje się ona w ramach wspólnoty Kościoła, który głosząc ewangeliczne orędzie o odkupieniu dokonanym w Jezusie Chrystusie i nawołując do wierności wobec sakramentalnej łaski Chrztu Świętego, ukazuje jednocześnie drogi i środki odnowy wszelkich struktur życia społecznego w ich konkretnej rzeczywistości dziejowej. W tym kontekście, prowadzony za pomocą różnorakich środków i metod programowy proces laicyzacji i ateizacji stanowił zatem ogromne zagrożenie zarówno dla kultury i tożsamości Polaków, jak też dla życia religijnego i moralnego Narodu. 
Fundamentem odnowy moralnej życia społecznego staje się odrodzenie w Chrystusie realizowane na drodze metanoi i pojednania z Bogiem. Wymaga to jednak radykalnego zwrotu ku Bogu, czego następstwem staje się przemiana sumień oraz pogłębienie świadomości i wrażliwości moralnej osoby ludzkiej, rodziny - a w konsekwencji również Narodu. Zmiana sposobu myślenia i wartościowania pociąga za sobą przemianę postaw, które ukierunkowane na świętość prowadzą do chrześcijańskiej doskonałości w Chrystusie. Tym samym, powrót do Boga przez Maryję (Soli Deo per Mariam) staje się więc podstawą odnowy moralnej całej rzeczywistości życia społecznego. Dokonuje się on zarówno na drodze ciągłej przemiany przeobrażającej serca i postawy poszczególnych ludzi oraz całej społeczności w wymiarze sakramentalnego pojednania z Bogiem w Kościele.

Słowa kluczowe: Kardynał Stefan Wyszyński; ideologia totalitarna; komunizm; personalizm; sekularyzacja; ateizacja; odnowa moralna. 